Full length research article

\section{PRODUCTION EFFICIENCY AND ECONOMIC POTENTIAL OF DIFFERENT SOIL FERTILITY MANAGEMENT STRATEGIES AMONG GROUNDNUT FARMERS OF KENYA}

${ }^{*} \mathrm{KIPKOECH}, \mathrm{A} . \mathrm{K}^{1}$, OKIROR, M. A.2 ${ }^{2}$ OKALEBO, J. R. ${ }^{1}$ \& MARITIM, H. K.

\author{
${ }^{1}$ Moi University, P.O. Box 3900-30100, Eldoret, Kenya \\ 2 Groundnut Research Project, Egerton University \\ P.O. Box 536, Njoro, Kenya \\ *(Corresponding author) \\ akkipkoech@yahoo.com or akipkoech@icipe.org
}

\begin{abstract}
This paper provides the economic evaluation of different soil fertility replenishing technologies (use of inorganic fertilizers, organic manure, and rhizobium inoculant) that were tested during field studies and recommended to groundnut farmers. Data on soil fertility technologies used by households, groundnut yields, and resource use and farm and farmers characteristics were collected through administration of a questionnaire to a sample of 332 farmers from three districts of western Kenya. The data was analyzed to determine whether adoption of the technologies would increase household incomes and production efficiency. Benefits and costs of each technology were computed through the use of budgets. Technical and allocative inefficiencies are investigated by fitting a Cobb-Douglas production function. The technical efficiency of the farmers varied between 0.56 and 0.69 while labor allocative efficiency varied between 0.81 and 0.93 . Farmers applying organic fertilizers only were technically more efficient but had lower potential yield compared to farmers who applied inorganic or a combination of organic and inorganic fertilizers. Use of inorganic fertilizers lead to a benefit cost ratio of up to 3:1. Organic manure had the lowest benefit-cost ratio (2.2:1) even when compared with that obtained when farmers did not apply any fertility replenishing input resulting from high cost of labor required to use this technology. There is a high potential for farmers to increase their groundnut yields and incomes by improving on production efficiency and by fertilizing their groundnut farms.
\end{abstract}

Key words: Cost-Benefit ratios, Groundnuts, Kenya, Production efficiency, Production function

\section{INTRODUCTION}

Vegetable oils form an important component of Kenya's import bill. Domestic production accounts for less than $20 \%$ of the domestic requirement despite a wide range of agro-ecological zones that can support a diverse range of oilseed crops (Rop et al. 1996; Demese et al. 1997). The important oilseed crops include simsim, coconuts, cotton, groundnuts, sunflower, rapeseed and soya beans. In most cases, production of these oilseed crops, especially groundnuts, is carried out by smallscale farmers as secondary crops, relay crops or inter-crops. Under the prevailing conditions and with the available resources, Kenyan farmers can increase domestic production of oilseed crops by $75 \%$ (ROK 1999). In western Kenya, the crop is not only the principal source of protein and oil but also a major source of small-holder cash income (Hilderbrand \& Subrahmanyan 1994). However, groundnut production has continued to decline with farmers realizing less that $50 \%$ of the yield potential.

Decline in soil fertility ranks high amongst the factors limiting food production in sub-Saharan Africa. Smaling (1993) shows that there has been a net nutrient loss in Kenya's soils in the last 30 years mainly due to crop harvests, crop residues, leaching, dinitrification, erosion and lack of soil nutrient replenishment. This is more pronounced in farms belonging to resource poor smallholder farmers. Woomer et al. (1997) noted that in every cropping season, plant nutrients are withdrawn from the soil through crop harvest and soil erosion at higher rates than they are replaced through fertilizer and organic matter application. With the high population growth rate in western Kenya of about $3 \%$, and the shrinking farm size per head, an agricultural boost is required to improve land productivity and generate extra funds for investment, which will have a positive multiplier effect on the rural economy (Delgado et al. 1994). Some of the tools available to provide this boost include use of fertility enhancing strategies e.g. application of organic and inorganic fertilizers.

Opportunities for developing and adopting better technologies provide a possible solution for raising productivity and improving efficiency (Ali \& Chaundhry 1990). Estimates on the extent of inefficiency can help to decide whether to improve efficiency or to develop new technologies to raise agricultural productivity.

There is evidence that farmers in developing countries fail to exploit fully the potential of a technology and/or make allocative errors with the result that yields varies widely between farms in western Kenya. This reflects a corresponding variation in farmers' management capacities. From studies carried out in Philippines, Dawson \& Lingard (1989) found 25-50\% inefficiency in rice production, and a positive relationship between efficiency and various management variables such as farmers' education, experience and information. Ali \& Flinn (1989) concluded that profits of rice farmers in Pakistan's Punjab could increase by $28 \%$ through improved efficiency.

Groundnut farmers in Western Kenya can be divided into four categories. Those who plant groundnuts without applying any fertility enhancing input, those using organic manure only, those using inorganic fertilizer only, and those applying both organic manure and inorganic fertilizer. A Comparison of agricultural production efficiency of the different categories of farmers will help to determine the effectiveness of adoption of soil fertility replenishment technologies among the groundnut farmers in the region. The comparison of resource allocation by different categories and their resultant efficiency will highlight the sources of possible farm-income disparities among the groups. Such analysis may help policy-makers to rationalize agricultural development policies in Western Kenya. The study is motivated by the fact that increasing farm level production efficiency provides the single best means by which farmers increase 
groundnut production without additional conventional inputs and with existing technologies. Determining the efficiency and income difference among users of different soil fertility replenishing technologies help in determining whether fertilization of groundnut fields is economically viable. It will also provide a basis for deciding whether to improve efficiency or to develop new technologies to raise groundnut productivity.

In this paper we measure farm efficiency using the estimated probabilistic frontier production function for adopters and nonadopters of soil fertility replenishment technologies in groundnut fields, in three districts of Western Kenya. The objective is to determine whether these technologies would help to increase farm incomes through computation of benefit-cost ratios and whether the technologies could increase the technical and allocative efficiencies of groundnut farmers.

\section{MATERIALS AND METHODS}

Study area: The study was carried out in three adjacent administrative districts of western Kenya, namely, Busia, Teso and Siaya. Busia district (latitudes $0^{\circ} 1^{\prime}-0^{\circ} 33^{\prime} \mathrm{N}$ and longitudes $33^{\circ} 54^{\prime}-34^{\circ} 25^{\prime} \mathrm{E}$ ) borders Teso to the North and Siaya to the South that makes the districts share some physical and environmental characteristics. The districts are characterized by high population density. The total population of the three districts is $1,066,569$, which is about $4 \%$ of Kenya's population (ROK 1997). This population depends on a total arable land of $5,287 \mathrm{~km}^{2}$. Busia district borders Siaya district to the South and Teso to the North The average population density varied from 311 to 365 persons per $\mathrm{Km}^{2}$. In Teso district, groundnut average production increased from 0.34 tons/ha in 1995 to 0.7 tons/ha in 1997 but decreased again to 0.4 tons/ha in 2000. In Busia average production has remained almost constant at 0.5 tons/ha. In Siaya, the average production decreased from 0.8 tons/ha in 1995 to 0.4 tons/ha in 1997 and increased to 0.8 tones/ha in 2000. The decrease in average production was attributed to high instances of groundnut rosette in the district. The Groundnut Research Project has however helped to increase the productivity of the land and is responsible for the upward trend of average production in the study districts.

Field Experiments: On-farm trials on the use of inorganic fertilizers at the rate of $150 \mathrm{Kg} / \mathrm{ha}$ of DAP or $100 \mathrm{Kg} / \mathrm{ha} \mathrm{NPK}$, organic manure at the rate of 11 tonnes/ha and seed inoculation using the rhizobium inoculan were conducted on farmers' fields. The fertilizers were applied in one level. Farmers were called in at all farm operation stages and recommended application procedures explained to them. Often participating farmers were asked to practice the application of the fertilizers and then encouraged to adopt the technologies.

Sampling Procedure: The number of farmers growing groundnuts varied between agro-ecological zones in the districts. In Siaya district, the on-farm trials were carried out in Ugenya and Ukwala divisions and thus the divisions were purposely selected. The whole of Teso district was included, while in Busia, the leading groundnut producing divisions, Butula and Matayos, were purposely selected for the study. The other divisions in Busia (Township, Budalangi and Funyula) had only small areas under groundnuts and were therefore, not included in the study. In each of the sample areas, the multi-stage sampling procedure was followed to select three locations. From each of the selected locations, two sub-locations were randomly selected as sample sites. The sample units were randomly selected using the systematic random sampling procedure from a list of farmers from the sample sites. Data was collected from 332 farmers through administration of a questionnaire.

Economic Analyses: The costs and benefits associated with the technologies were determined. The values used depended on the market prices at the end of year 2000 production season. The benefit of groundnuts for soil replenishment was based on the $100 \mathrm{Kg} \mathrm{N} / \mathrm{ha}$ added over the plant establishment period and was estimated on the basis of cost of $\mathrm{N}$ fertilizer. The benefits of the crop were therefore taken to include the value of the yields and the value of nitrogen added to the soil. Labor requirements for land preparation, fertilizer application, planting, weeding, harvesting and post harvest operations were obtained from field interviews. The labor wage rates depended on the number of hours worked. Groundnut seed was calculated on the basis of $30 \mathrm{Kg} / \mathrm{ha}$ at the cost of Kshs. 65 per $\mathrm{Kg}$. This was the average peak season price for groundnuts. All operations were assumed to have been carried out by a contractor. Where family labor was used, opportunity cost of labor was used to calculate its cost.

Analytical framework: Technical and allocative inefficiencies are often investigated using production function models. The basic model used to measure technical and allocative efficiencies in case of one variable and one output is illustrated in Figure 1. The curve TPPm shows the maximum possible total output as input $X$ is increased, while TPPn shows the input response on an average farm. All points lying below TPPm are technically inefficient because they give less output at given levels of input. Micro-economic theory holds that for profit maximization, firms should produce at the point where the marginal value product of a resource equals its price. Therefore, for farmers to maximize their profits, they will produce at $\mathrm{Y}$, which is technically and allocatively efficient. Technical efficiency is defined as the ratio of farmers' actual output to the technically maximum possible output at the given level of resource use $(Y 1 / Y 3)$ and computed as $1-Y 2 / Y 3$. Allocative efficiency is expressed as the ratio of technically maximum possible output at the farmers' level of resources (Y3/Y1), which can also be expressed as $1-Y 3 / Y 1$. Economic efficiency is the product of technical and allocative efficiencies.

The general form of a Cobb-Douglas production function is stated as:

$$
Y=A x_{1}^{\alpha_{1}} x_{2}^{\alpha 2} \mu
$$

Where: $Y$ is the output, $X_{1}$ and $X_{2}$ are inputs. $A$ is the intercept and $\alpha_{1}$ and $\alpha_{2}$ defines the transformation ratio of the inputs. 


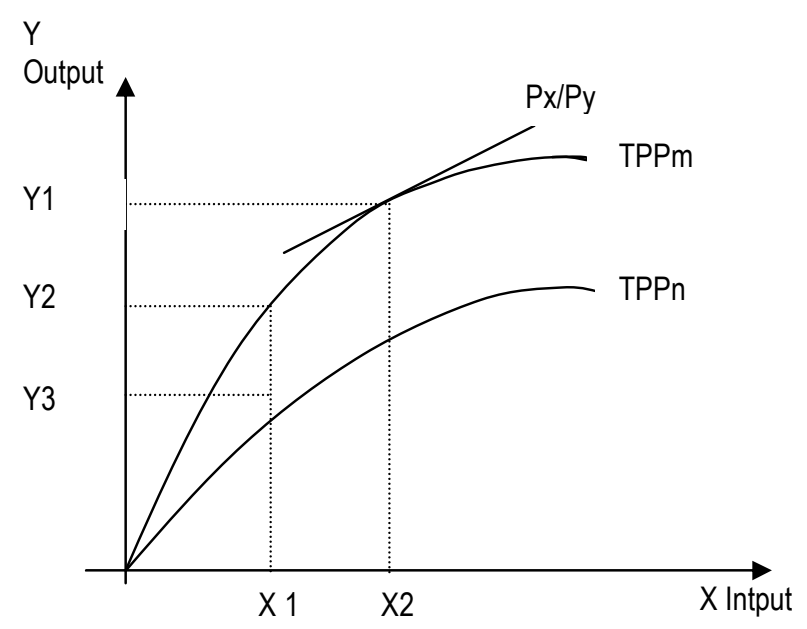

\section{FIG. 1 GRAPHICAL REPRESENTATION OF TECHNICAL AND ALLOCATIVE EFFICIENCY}

$\mu$ is the error term assumed to capture the influence of random variables such as weather, pests and disease. The terms $A$ denotes technical efficiency, with the farms being equally technically efficient if $A s$ for all the farms are equal. The production function by ordinary least squares (OLS) shows the average response (TPPn) and does not qualify for the theoretical definition of production function or frontier (Ali \& Chaundhry 1990). This problem can be overcome by constraining all the error terms to lie on or above the frontier. The problem with this is that, the outliers seriously affect the coefficients. Timmer (1971) used probabilistic frontier function to overcome this problem, which deletes outlier observations, one at a time, to avoid spurious errors due to extreme observations until the resulting estimates stabilize.

The error term $\mu$ is assumed to be randomly and normally distributed and thus can be estimated using the OLS. To transform equation (i) into a deterministic frontier function, the $\mu$ of all categories of farmers are constrained to be positive. In this case the estimated maximum output will be greater than or equal to the observed output. Thus (i) is estimated such that

$$
\mu_{\mathrm{j}} \geq 0 \quad \text { or } \quad \hat{y}_{j} \geq y_{j}
$$

Only a technically efficient farm will meet this criterion. All other farms will have an output less than their potential. The problem is

Minimize $\quad \sum_{j=1}^{n} U_{j}$
Subject to $\hat{y}_{j} \geq y_{j}$
$\mathrm{j}=1,2, \ldots, \mathrm{n}$
(iii)

This is solved using linear programming to avoid explosion. It can be proved that sum of $\mu_{\mathrm{j}}$ over all farms is approximately equal to the estimated value of output evaluated at the mean values of inputs and so the objective function in (iii) can be altered accordingly.

$$
\sum_{j=1}^{n} u_{j} \sim \sum_{i=0}^{m} b_{i} \ln \bar{x}_{i}
$$

where $\bar{x}=(1 / n) \sum_{j=1}^{n} x_{i j}$

From the probabilistic function coefficients, farm specific technical efficiency $\left(T E_{j}\right)$ is measured as:

$\mathrm{TE}_{\mathrm{j}}=\mathrm{AO}_{\mathrm{j}} / \mathrm{MPO}_{\mathrm{j}} \quad$ or $y_{j} / \hat{y}_{j}=e^{-u j}$

Where $\mathrm{AO}_{\mathrm{j}}$ is actual output of $\mathrm{j}$-th farmer, $\mathrm{MPO}_{\mathrm{j}}$ is maximum possible output of $\mathrm{j}$-th farmer $\left(\mathrm{y}_{\mathrm{j}}\right)$. MPO $\mathrm{j}$ is obtained by substituting the $j$-th farmers level of resources into the estimated probabilistic frontier production function. Farm specific allocative efficiency $\left(A E_{i j}\right)$ in the use of variable input (i) is given as

$A E_{i j}=M P O_{j} / O R L_{i j}$

Where $O R L_{i j}$ is the gross revenue at optimal level of the $i-t h$ input. Farm specific optimum input level $\left(X^{*}{ }^{*}\right)$ is calculated by equating Marginal Value Product (MVP) of an input with the price of that input.

The allocative efficiency $\left(A E_{j}\right)$ of all inputs in $j$-th farm is estimated to be

$\mathrm{AEj}=\mathrm{MPO}_{\mathrm{j}} / O \mathrm{RL}_{\mathrm{j}}$

Where ORLj is the $j$-th farmer's gross revenue at the level of all variable inputs.

Empirical model: The production function is estimated from data collected between June 2000 and May 2001 through farm surveys and the farm efficiency measured in terms of technical efficiency (TE), allocative efficiency (AE) and economic efficiency (EE). The estimated Cobb-Douglas production function is estimated as:

$\operatorname{Ln} Y=A+\alpha_{1} \operatorname{Ln} X_{1}+\alpha_{2} \operatorname{Ln} X_{2}+\alpha_{3} \operatorname{Ln} X_{3}+\alpha_{4} \operatorname{Ln} X_{4}+$

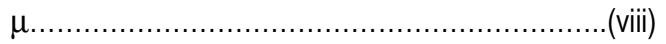

Where: $A=$ Groundnut output in bags, $\operatorname{Ln}=$ Logarithm to base e, $\mathrm{X}_{1}=$ Cost of labor in (KShs.), $\mathrm{X}_{2}=$ Cost of agricultural capital assets (Farm power in KShs.), $X_{3}=$ Land rent (Kshs), $X_{4}=$ Education level of household head, $\mu=$ Random error term that accounts for the unpredictable variation in outputs due to such variables as the weather, pests and diseases, $\alpha_{1}, \alpha_{2}, \ldots, \alpha_{4}$ =Technical coefficients (Elasticities).

The production function in (viii) was first estimated using OLS method for each category of groundnut producers and then 
transformed to a deterministic frontier production function as in (ix).

Minimize

$A+\alpha_{1} \operatorname{Ln} \bar{X}_{1}+\alpha_{2} \operatorname{Ln} \bar{X}_{2}+\alpha_{3} \operatorname{Ln} \bar{X}_{3}+\alpha_{4} \operatorname{Ln} \bar{X}_{4}$ Subject to

$\alpha_{1} \operatorname{Ln} X_{1}+\alpha_{2} \operatorname{Ln} X_{1}+\alpha_{3} \operatorname{Ln} X_{1}+\alpha_{4} \operatorname{Ln} X_{1} \geq Y_{1}$

$\alpha_{1} \operatorname{Ln} X_{2}+\alpha_{2} \operatorname{Ln} X_{2}+\alpha_{3} \operatorname{Ln} X_{2}+\alpha_{4} \operatorname{Ln} X_{2} \geq Y_{2}$

$\alpha_{1} \operatorname{Ln} X_{N}+\alpha_{2} \operatorname{Ln} X_{N}+\alpha_{3} \operatorname{Ln} X_{N}+\alpha_{4} \operatorname{Ln} X_{N} \geq Y_{N}$

Where $\bar{X}_{1}, \bar{X}_{2}, \bar{X}_{3}, \bar{X}_{4}$ are the mean values of the respective inputs.

The probablistic-fuction coefficients used in estimating efficiencies were obtained from Equation (ix) after deleting outlier observations until estimated coefficients stabilized. Allocative efficiency for labour was estimated. Farm power and other capital assets were not evaluated because data from a short period survey was not adequate to asses such inputs where scale adjustments depend on long-run profitability of the farm.

\section{RESULTS}

Each of the technologies had unique advantages (Table 1). When farmers applied inorganic fertilizers (DAP and NPK) or farmyard manure, germination was excellent so long as the fertilizer was well mixed with the soil before placing the seeds as compared to the low germination when no fertilizer was applied. This may provide a clue about low $\mathrm{P}$ availability in the area. Studies carried out in western Kenya have reported $P$ as being a limiting nutrient in many soils in the area (Smaling 1993). It is always very difficult for the crop production system to replenish $P$ stocks through the natural recycling processes in $P$ deficient soils (Buresh et al. 1997). Such replenishment may be achieved only through external application of $P$. The excellent germination could have resulted from the applied $P$, which helped in root formation that translated to benefits of increasing the number of pods per plant and consequently, crop production and income to farmers.
The rates of application of fertilizers by farmers who adopted the use of fertilizers were however, low. The poverty level in the area was high and farmers made priorities on how available resources were to be applied in the production system. Faced with these circumstances, application of livestock manure and inorganic fertilizer was limited to high value crops (Reardon \& Vosti 1997). The value attached to the crops depended on family's priorities, resources and socio-economic factors such as education and sex of household head. The use of manures was expected to lead to varied yield in different seasons and regions. This was because the nutrient level of manure depended on the animal feed, handling and storage systems (Chikowo et al. 1999), which varied in time and space.

The moisture stress in dry periods also reduced with application of inorganic fertilizers. This was as a result of the influence of the fertilizers on the growth vigor of the plant. When groundnut was planted as a mono-crop, fields fertilized with inorganic fertilizers had huge canopies that reduced water loss from the soil through evaporation. The mid season moisture stress inhibits Ca uptake (Cox et al. 1982) and probably contribute to increased pod development failure for manure fertilization and the control.

Economic benefits of the technologies: A technology is attractive to the point in which the cost incurred in its adoption is fully offset by the benefits and the farmer rewarded for adopting it. The use of an embodied technology requires the farmers to purchase the inputs in order to reap the benefits from that technology. The most evident advantage of adoption of the technologies was the increase in yields that was realized from every technology. The percentage increase however, differed according to the technology. To illustrate the net benefits of full adoption of these technologies, each of the technologies was scrutinized in cost benefit analyses. The analyses evaluated these technologies against controls over one cropping season. The net benefit values were calculated on per hectare basis. The advantages of adopting these technologies are given in Table 2.

All seeds planted were sorted to remove defective ones. Red Valencia groundnut variety was planted in all cases $(+)$ refers to technology present

TABLE 1: ADVANTAGES OF USING SOIL FERTILITY REPLENISHING TECHNOLOGIES

\begin{tabular}{llllll}
\hline \multicolumn{1}{c}{ Technology } & \multicolumn{1}{c}{ Control } & \multicolumn{1}{c}{ DAP } & \multicolumn{1}{c}{ NPK } & \multicolumn{1}{c}{ FYM } & Rhizobium inoculant \\
\hline Germination & ${ }^{1}$ Moderate & 2Excellent & 2Excellent & Excellent & Moderate \\
\hline Moisture stress in dry periods & Moderate & Reduced & Reduced & Moderate & Moderate \\
\hline Approximate pods/plant & 10 & 30 & 23 & 13 & 18 \\
\hline Growth viqour & Poor & $\begin{array}{l}\text { Good robust } \\
\text { plants }\end{array}$ & $\begin{array}{l}\text { Good robust } \\
\text { plants }\end{array}$ & $\begin{array}{l}\text { Good robust } \\
\text { plants }\end{array}$ & Moderate vigor \\
\hline Yields Kg/ha & 1208.7 & 1800 & 1646 & 1218.5 & 1362.9 \\
\hline
\end{tabular}

${ }_{1}>90 \%$ when soils are naturally fertile

${ }^{2}$ Nil germination without thorough mixing with the soil 
TABLE 2: BENEFITS AND COST OF SOIL FERTILITY REPLENISHING TECHNOLOGIES

\begin{tabular}{|c|c|c|c|c|c|c|c|c|c|}
\hline & \multicolumn{8}{|c|}{ Technology } \\
\hline & & \multicolumn{2}{|c|}{ Seedbed } & \multicolumn{2}{|c|}{$\begin{array}{l}\text { No. of } \\
\text { weedings }\end{array}$} & \multirow[t]{2}{*}{$\begin{array}{l}\text { Red } \\
\text { Valencia }\end{array}$} & \multirow[t]{2}{*}{$\begin{array}{l}\begin{array}{l}\text { Total Benefits } \\
\text { (Kshs.) }\end{array} \\
\end{array}$} & \multirow[t]{2}{*}{$\begin{array}{l}\text { Total Costs } \\
\text { (Kshs.) }\end{array}$} & \multirow[t]{2}{*}{$\begin{array}{l}\mathrm{B} / \mathrm{C} \\
\text { ratio }\end{array}$} \\
\hline & & Rough & Smooth & 1 & 2 & & & & \\
\hline 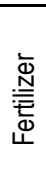 & $\begin{array}{l}\text { Rh. Inoculant } \\
\text { DAP } \\
\text { NPK } \\
\text { Organic manure } \\
\text { Control }\end{array}$ & & $\begin{array}{l}+ \\
+ \\
+ \\
+ \\
+\end{array}$ & & $\begin{array}{l}+ \\
+ \\
+ \\
+ \\
+\end{array}$ & $\begin{array}{l}+ \\
+ \\
+ \\
+ \\
+\end{array}$ & $\begin{array}{l}90430 \\
118900 \\
108890 \\
81102 \\
78565\end{array}$ & $\begin{array}{l}35826 \\
38999 \\
38507 \\
37130 \\
32531\end{array}$ & $\begin{array}{l}2.5: 1 \\
3.0: 1 \\
2.8: 1 \\
2.2: 1 \\
2.4: 1\end{array}$ \\
\hline
\end{tabular}

All seeds planted were sorted to remove defective ones.

Red Valencia groundnut variety was planted in all cases

+ refers to technology present

Apart from using organic manure, groundnut production was more profitable with the other nutrient replenishing technologies (Table 2). This was attributed to the fact that adoption of organic manure required more man-hours for collection and application. Application of manure also led to high infestation of weeds that needed extra man-hours to control. This cost however translates to family incomes since most of the farm labor was obtained from the households.

Technical and Allocative Efficiency: The regression values in Table 3 show that labor was significant in most of the technologies. This is because external inputs are seldom used and therefore, the output of groundnuts depends more on application of labor in the production system. Labor determines how well farm operations such as plowing, weeding and harvesting are done. These farm operations in turn influence plant growth through influencing how easy the groundnut plants will extract nutrients and water from the soil. The contribution of land in the production of groundnut was only significant for control and inorganic fertilizer. In most households, groundnuts were planted as intercrop or relay crop and cultural practices such as row planting were hardly used. In this way, plant populations achieved by most farmers per area were less than optimal. Adopters of inorganic fertilizers were more likely to be more entrepreneurial and more concerned on optimal use of resources. The management variable captured by education level of the farmers was not significant for all technologies.

After the farmers adopted the technologies that were recommended in part or as a package it was important to assess their efficiency. The test for relative efficiency of the different categories of technology adopters was possible through the parametric specification of the production function for each group. By using both inorganic and organic fertilizers, farmers became the most inefficient category groundnut producers. Non-adopters were the most efficient group followed by the organic manure adopters.

It follows therefore that adoption of the technologies did not increase the efficiency of farmers. Farmers incur more costs but fail to realize commensurate increases in yields. The family resource base may not have been optimally utilized when using improved technologies. Technologies such as application of manure need many man-hours, which is costly to farming households.

The highest allocation efficiency was achieved from farmers who used organic manure in the groundnut production (Table 4). This is probably because of the increase in the number of manhours required to collect and apply manure. The labor usage was nearly optimal for all categories of farmers, an indication that labor may be limiting in some seasons.

The technical efficiency of $55-69 \%$ obtained in this study is comparable to the mean technical efficiency estimates reported by several other studies in agriculture. For example, Sharma \& Leung (2000) reported a mean technical efficiency of 80.5 and $65.8 \%$ for semi-intensive/intensive and extensive carp producers respectively in India while Alene \& Hassan (2005) reported a mean TE of 68 and $78 \%$ for traditional and hybrid maize producers in Eastern Ethiopia respectively. Datt \& Joshi (1992) reported a mean TE of $66 \%$ in rice production in Uttar radish, India.

Results from this study shows that the use of organic or inorganic fertilizers in groundnut fields improves the profitability and labor allocation efficiency in the study areas. Technical efficiency did not improve with adoption of the technologies. The technical efficiency coefficients ranged from 0.69 (for the nonadopter) to 0.56 for adopters of both organic and inorganic fertilizers. This means that there is a potential for groundnut farmers to increase their incomes by $31-44 \%$. Although adoption of the fertility replenishment technologies improves profitability of groundnut farming, adoption may not necessarily improve the farmer's technical efficiency. Labor allocation efficiency was lowest for farmers using traditional technologies. Adoption of these technologies will improve allocation efficiency of labor. It was observable that labor use was however almost optimal. Technology developments to substitute labor especially in peak seasons will help increase groundnut production. A profitable technology is not necessarily economically efficient. 
TABLE 3: THE COBB-DOUGLAS PRODUCTION FUNCTION PARAMETERS

\begin{tabular}{llllllll}
\hline \multicolumn{1}{c}{ Technology } & Constant & Land & Farm power & Labor & Education & $\mathbf{r}^{2}$ & $\mathbf{F}$ \\
\hline No fertilizer & $-1.35^{*}$ & $1.35^{*}$ & $1.18^{*}$ & -0.004 & -0.11 & & \\
& $(0.62)$ & $(0.12)$ & $(0.27)$ & $(0.07)$ & $(0.09)$ & 50.9 & 55.5 \\
Organic manure & $-1.83^{*}$ & -0.11 & $0.91^{*}$ & $0.33^{*}$ & 0.11 & & \\
& $(0.34)$ & $(0.11)$ & $(0.29)$ & $(0.06)$ & $(0.08)$ & 40.1 & 11.8 \\
Inorganic fertilizer & $-3.35^{*}$ & $1.45^{*}$ & $1.98^{*}$ & $0.42^{*}$ & 0.02 & & \\
& $(1.52)$ & $(0.24)$ & $(0.71)$ & $(0.20)$ & $(0.20)$ & 74.8 & 17.0 \\
Organic and inorganic & $-7.63^{*}$ & 0.23 & 2.4 & $0.49^{*}$ & 0.46 & & \\
& $(3.3)$ & $(0.32)$ & $(1.68)$ & $(0.06)$ & $(0.92)$ & 51.1 & 2.6 \\
\hline * Significant at $P<0.01$ & & & & & & &
\end{tabular}

* Significant at $P<0.01$

Figures in the brackets are the standard errors (S.E.)

TABLE 4: EFFICIENCY COEFFICIENTS FOR DIFFERENT TECHNOLOGY ADOPTERS

\begin{tabular}{llcll}
\hline & \multicolumn{4}{c}{ Type of fertilizer used } \\
Efficiency & None & organic & inorganic & organic + inorganic \\
\hline Technical & 0.69 & 0.62 & $0.55^{*}$ & $0.56^{*}$ \\
& $(0.09)$ & $(0.07)$ & $(0.10)$ & $(0.13)$ \\
Labor allocation & 0.81 & 0.93 & $0.89^{*}$ & $0.88^{*}$ \\
& $(0.07)$ & $(0.06)$ & $(0.05)$ & $(0.08)$ \\
\hline
\end{tabular}

Similar superscripts on figures in rows imply they are statistically equal $(p<0.01)$.

\section{ACKNOWLEDGEMENT}

We are very grateful to Rockefeller Foundation for funding this research for without them this research could never have been. Thanks to all the organisations and individuals who oriented us to the districts and whose staff helped in data collection. We also thank all the farmers in the district who attended the field days that were organised by the project and adopted the technologies developed. By so doing they helped in translating the technologies from a concept to a reality.

\section{REFERENCES}

Alene, A. D. \& Hassan, R. M. 2005. The efficiency of traditional and hybrid maize production in eastern Ethiopia: an extended efficiency decomposition approach. Journal of African Economies, 15: 91-116

Ali, M. and Flinn, J. C. 1989. Profit efficiency among Basmati rice produces in Pakistan Punjab. American Journal of Agricultural Economics, 303-310.

Ali, M. \& Chaudhry, M. A. 1990. Inter- Regional Farm Efficiency in Pakistan's District of Punjab, a Frontier Production Function. Journal of Agricultural Economics, 411. 62-75.

Buresh, R. J.; Smithson, P. C. \& Hellums, D. Y. 1997. Building Soil Phosphorus Capital in Africa. In. Replenishing Soil Fertility in Africa, edited by R. J. Buresh et al. SSSA spec. Publ. 51. SSSA, Madison, USA
Chikowo, R,; Tagwira, F. \& Piha, M. 1999. Agronomic Effectiveness of Poor Quality Manure Supplemented with phosphate fertilizers on maize and groundnut in maizegroundnut rotation, African Crop Science Journal, 74:383-396.

Cox, F. R.; Adams F. \& Tucker, B. B. 1982. Liming, Fertilization and Mineral Nutrition In Peanut Science and Technology. Edited by Pattee, $\mathrm{H}$ \& Young C. American Peanut Research and Educational Society

Datt, K. K. \& Joshi, P. K. 1992. Economic efficiencies and land augmentation to increase agricultural production: a comparative analysis for investment priorities. Indian Journal of Agricultural Economics, 47: 468-476.

Dawson, P. J \& Lingard. J. 1989. Measuring Farm Efficiency over Time on Philippine Rice Farms. Journal of Agricultural Economics, 40: 168-177.

Delgado, C. L.; Hopkins, J. \& Kelly, V. 1994. Agricultural Growth Linkages in Sub-Saharan Africa: A Syhtesis. Proceedings of a workshop on Agricultural Growth Linkages in sub-Saharan Africa, International Food Policy Research institute, Washington DC, pp 22-26

Demese, C.; Rop, I. K. \& Maritim, H. K. 1997. Vegetable Oils/Protein Production to Consumption System Analysis in Kenya. Workshop Proceedings on Vegetables Oil/Protein System, 29th-30th April .1997. Egerton University, Njoro. 
Hilderbrand, G. L. \& Subrahmanyan, P. 1994. Genetic Enhancement of Groundnuts: Its role in sustainable Agriulture. Seminar proceedings on sustaining soil productivity in intensive African Agriculture 15-19 November 1993, Accra, Ghana, Technical Center for Agricultural and rural crop, The Netherlands, pp 5-12.

Reardon, T. R. \& Vosti, S. A. 1997. Policy Analysis of Conservation Investment: Extension of Traditional Technology Adoption Research, In: Sustainability, Growth and Poverty alleviation: Policy and Agroecological Perspectives, edited by Vosti S. A. \& Reardon T. R., John Hopkins Press, Baltimore, USA

Republic of Kenya (ROK) 1997. District Development Plan 1997-2001 Office of the Vice President and Minister of Planning and National development, Government Printer, Nairobi, Kenya.

Republic of Kenya (ROK) 1999. Economic Review. Government Printer, Nairobi.

Rop, I. K.; Ouma, S. \& Ogoye, H. 1996. Production Structure of Vegetable Oilcrops in Kenya, final Report. unpublished. VOPSK Project, Egerton University, Njoro.
Sharma, K. R. \& Leung, P. S. 2000. Technical efficiency of carp production in India: a stochastic frontier production function analysis. Aquaculture Research, 31: 937-947

Smaling, E. M. A. 1993. An Agroecological Framework for Integrating Nutrient Management, with Special Reference to Kenya. University Ph D thesis, Weningen, The Netherlands, pp 250.

Timmer, C. P. 1971. Using a probablistic Frontier Production Function to Measure Technical Efficiency, Journal of Political Economy, 794:776-794.

Woomer, P. L.; Kotto-Same, J.; Bekunda, M. A. \& Okalebo, J. R. 1997. The Biological Management of Tropical Soil Fertility. Some Research and Development Priorities for Africa. Proceedings of Workshop 8 on Long-term Soil Management Research in the Tropics Ohio State University Columbia, $\mathrm{OH}$. 